\title{
SCIENTIFIC AND PROFESSIONAL DISCOURSE IN THE VOCATIONAL TRAINING OF UKRAINIAN PHILOLOGISTS
}

\section{Holikova N. S.}

\section{INTRODUCTION}

Ukrainian society needs to be restructured in the field of educational and vocational training of young professionals as in the context of today the society is at the turn of worldview and is facing global transformations in all life spheres. At the beginning of the XXI century the elaboration and implementation of a learner-centered model of development of scientific and professional language of students was one of the urgent tasks of higher education institutions, in particular those where Ukrainian philologists are taught. Structuring the classification matrix, that is designed to train a professional, allows to create an appropriate scientific and theoretical basis for each specialist to further master the terminological system of the Ukrainian language as the most important way of communication. This is relevant not only during Ukrainian language and literature classes in various secondary schools but also in other educational and cultural institutions, government agencies, which require the professional contribution of philologists of Ukrainian studies. Until recent times the philological faculties graduate of a number of classic universities in Ukraine mostly held the positions of teachers in secondary schools. However, in the conditions of further development of the state and strengthening of its social systems the range of professional employment in the field of Ukrainian philology has significantly expanded. Nowadays university graduates can work in the scientific, literary and publishing fields; in printed and electronic mass media and PR-technologies; in various foundations, including humanitarian, in unions; in museums, art and cultural centers, etc. That is why philologists of Ukrainian studies have to show sustainable level of professional knowledge and professional manner in various communication situations, they have to be competitive in the employment market.

The development of higher education in the field of philology, in particular Ukrainian linguistics, requires the search for new ways of implementing the educational program, the formulation of special guidelines for the practical application of the Ukrainian language knowledge acquired by students while studying at university. As a consequence, scientific and practical anthropocentric courses become relevant in the system of linguistic disciplines offered to applicants for higher education in the field of 
Ukrainian philology. Recently, it has been observed that new tendencies for teaching the Ukrainian language to students of both philological and nonphilological majors are developing in the linguo-didactics of higher education institutions. The most common of them are anthropocentric, functional-communicative, learner-centered, and other scientific and educational approaches that provide proper training of experts, develop their language and professional behaviors with a focus on their successful implementation in certain fields. For the philologists of Ukrainian studies one of the priority fields of vocational training is discourse and anthropocentric approach. It is implemented by means of particular linguistic disciplines of the elective course.

In modern linguistics the study of various linguistic facts is more often conducted with the slogan of discourse-centrism. N. Arutyunova defines the concept of discourse as follows "Discourse is a coherent text with extralinguistic factors those are pragmatic, socio-cultural, psychological and others; the text taken in the aspect of events; speech considered as a purposeful social action and as a component that is involved in people's interaction and the mechanisms of their consciousness (cognitive processes). Discourse is speech "immersed in life" ${ }^{1}$. This interpretation emphasizes the features of discourse that motivate changes in educational programs of various fields of philology and other fields. However, the real ways of implementing the discursive field in the language training of Ukrainian philologists require more thorough analysis.

\section{Typological features of professional discourse}

In the linguistics of the end of the XX - beginning of the XXI century language is more often considered as a dynamic phenomenon, which is the most active form of communication in all aspects of public life. The traditional study of systemic connections between lingual units of different levels is gradually going through a theoretical and conceptual reorientation in the aspect of scientific development of the "humanization" of language, which has always been relevant in the history of philosophy and other humanities. Recently, new and non-trivial problems have been the subject of study, and within linguistics the number of papers devoted to the role of language in the formation of the cultural-semiotic component of social consciousness is rapidly increasing. As K. Serazhym notes «the interests of researchers shifted from the structural description of language to the study of the historical context

1 Арутюнова Н.Д. Дискурс. Лингвистический энциклопедический словарь / гл. ред. В.Н. Ярцева. Москва : Сов. энциклопедия, 1990. С. 136-137. 
in which language develops and functions"2. It is no coincidence that in modern linguistics the decisive place belongs to human space, which, according to F. Batsevich, O. Revzina, is constituted by individuals who perform appropriate communicative, social, interpersonal, ideological, psychological roles by means of communicating with each other ${ }^{3}$.

One of the main linguistic issues of Ukrainian studies is a comprehensive study of the concept of discourse, which reflects a variety of real manifestations of communication in certain social spheres of human's communicative space. Maintaining of this concept in various scientific fields, whose representatives study the nature and mechanisms of interaction between constants of such linguistic and philosophical dichotomies as "language and society", "language and man", necessitated its clear definition, as well as the development of typology discourses, defining their main categorical features, etc. Currently there is no one single approach to their study within the theory of discourse even though linguists use a number of methods of discursive analysis of linguistic units.

Differentiation of discourses is one of the most important issues of modern discourse. This is currently a problem that researchers solve differently based on a wide range of different socio-linguistic manifestations of communication. While studying discourse as a sociolinguistic phenomenon, K. Serazhym explains: "The diversity of communicative situations in which discursive activity occurs and generates the variety of discourses"4. As many other linguists who joined the theoretical generalization of the achievements of science (N. Kondratenko, V. Korolyova, M. Makarov, G. Pocheptsov, A. Prikhodko etc.) the researcher emphasizes the lack of universal criteria for the classification of discourses, which has led to the selection of their various types such as: pedagogical discourse, parental discourse, ethical discourse, religious discourse, scientific discourse, critical discourse, political discourse, administrative discourse, business discourse, legal discourse, military discourse, sports discourse, medical discourse, advertising discourse, media discourse 5 . This classification indicates a broad understanding of the

${ }^{2}$ Серажим К. Дискурс як соціолінгвальне явище: методологія, архітектоніка, варіативність : монографія. Київ : Видавець Паливода А. В., 2010. С. 9.

3 Бацевич Ф.С. Філософсько-метологічні засади сучасної лінгвістики: спроба обгрунтування. Мовознавство. 2006. № 6. С. 35; Ревзина О. Г. Лингвистика XXI века: на путях целостности теории языка. Критика и семиотика. Новосибирск, 2004. Вып. 7. С. 12.

${ }^{4}$ Серажим К. Дискурс як соціолінгвальне явище: методологія, архітектоніка, варіативність : монографія. Київ : Видавець Паливода А. В., 2010. С. 49.

${ }^{5}$ Там само. С. $49-50$. 
concept of "discourse", which can be implemented in any social sphere including educational and vocational training of future philologists. On the one hand the illustrated (individual-authorial) typology of discourses requires even more detailed differentiation, and on the other hand within a broader concept it requires the unification of some of them. We suppose most of the selected discourses presented in this list (e.g. pedagogical, administrative, business, legal, medical, etc.) can be integrated as components that specify a broader semantic-categorical concept that is professional discourse.

During the last decades (the end of the XX - the beginning of the XXI century) the number of researches devoted to the comprehensive characterization of discourse in various branches of science, in which professional discourse is oftenstudied in relation to certain scientific texts has increased. Such a phenomenon is considered within the framework of semiotics, social psychology, the theory of artificial intelligence, literary criticism, philosophy, and others. The concept of professional discourse is also relevant in various areas of linguistic Ukrainian studies - in psycholinguistics, cognitive linguistics, conceptualism, communicative linguistics, linguopragmatics, ethnolinguistics, linguoculturology. Mastering the theoretical basis of these newest fields offers great opportunities for the transfer of the university educational and scientific sphere to a higher structure level. A solution to a number of issues serves a purpose in the process of restructuring the traditional system of training of philologists. The issues are the following: 1) establishment of categorical and typological signs of professional discourse; 2) identification of its specific features in the field of philology, linguistics in particular; 3) specifying the concept of "professional discourse" in the context of the educational standard of the specialty "Ukrainian language and literature"; 4) development of scientific and practical courses designed for comprehensive professional training of Ukrainian specialists.

Professional discourse can be characterized as a synthesis of professional identities implemented in the communicative activities of modern specialists. The study of the structure of such a discourse involves identifying the features of architectonics, in the basic principle of its construction, connections and interdependencies between the elements that are a single object $^{6}$, focused on different levels of professional communication. Therefore, information in all parts of the analyzed discourse, which are formed by real professions, is interpreted with the help

6 Голованова Е.И. Категория профессионального деятеля: Формирование. Развитие. Статус в языке. Москва : Изд-во «Элпис», 2008. С. 70. 
of relevant language signs. They are terminological semiotic systems, which include specialized names of those realia and concepts that reflect the specific contents of the profession.

Over a period of a few last decades there have been some changes in the views of scholars on the concept of "professional discourse". It is often associated with structural, institutional and corporate discourses, workspace discourse etc., which in fact have shared fields with similar forms of communication and its linguistic support. The main features which are common for professional and some related discourses are typically considered in terms of the functions they can fulfill. The theoretical basis to solve the problem, researchers often found in the works of foreign scientists $F$. Chiappini, K. Nikkersona, P. Linella et al., On which they rely, analyzing the specific professional and other, similar in content and purpose discourses ${ }^{7}$.

When analyzing the peculiarity of professional and other related discourses the researchers often rely on the theoretical basis they find in the works of foreign scholars. A branched classification matrix has been developed in Ukrainian linguistic studies, within which numerous variations are distinguished. It has been elaborated in order to describe professional discourse comprehensively and to identify its typological features. For example, I. Shevchenko and O. Morozova suggested the following criteria for distinguishing types and subtypes of discourse: 1) by form: oral and written; 2) by type of speech: monologic or dialogic; 3) by destination: institutional and personal (existential); 4) by different guidelines and communicative principles: argumentative, conflicting and harmonious discourses; 5) by socio-situational characteristics: political, administrative, legal, military, religious, medical, business, advertising, pedagogical, sports, scientific, electronic (Internet discourse), media discourse (mass media), etc ; 6) by various characteristics of the addresant and the addressee: sociodemographic criteria (children's discourse, discourse of adolescence, the discourse of the elderly, women and men discourses, the discourse of urban and rural residents); socioprofessional criteria (the discourse of sailors, builders, miners); socio-political criteria (the discourse of communists, democrats); 7) by functional and informative components: informative communication (affective, appraisive, directory discourses) and actual; 8) by thematter of form and content in the functional and stylistic aspect according

7 Войтко Т.В. Підходи до встановлення типології професійного дискурсу. URL: http://www.philol.vernadskyjournals.in.ua/journals/2019/3_2019/part_2/16.pdf. 
the genres and speech registers: artistic, publicistic, scientific and others, official and informal ${ }^{8}$.

Despite the efforts researchers make to classify in detail the demonstration of professional discourse in real scopes of its application it needs to be modified and improved. Particularly it is possible to clarify the content of pedagogical and scientific discourses that are specifically relevant for higher education institutions which provide training for the future Ukrainian philologists. This clarification can be based on socio-situational parameter as one of the criteria for typological identification and distinction of components of professional discourse. In this case, the pedagogical discourse, which is more common for secondary education, is transformed into academic. That is so because the main task of students who are preparing for professional activities in the educational program "Ukrainian language and literature" is to acquire theoretical knowledge and practical skills in the field of philology. Regarding this, it is necessary to clarify the typological features of scientific discourse, which should be adapted to the communicative tasks, emphasized by the specific features of the process of education, which the philological faculties of a number of universities provide.

\section{Scientific discourse in the field of professional training of the Ukrainian philologists}

Comprehensive study of scientific discourse as a kind of professional discourse involves various aspects of analysis, as well as certain research methods and procedures that allow to identify its specific features in connection withthe educational program of professional training of future Ukrainian philologists. According to our observations, the concept of "scientific discourse" fits naturally into a complex system, which consists of other numerous concepts, semantically and logically close to each other, but those that may differ significantly in their functions and sociocommunicative areas of application. This means that the concept of "scientific discourse" is correlated with representatives of a number of logical and semantic categories, which differently outline the coordinates of the branched research field, which has the analyzed discourse as its center. We believe that the isolation and description of typological features common for scientific discourse require taking into account the relationship of the studied object with a number of dimensions that determine its position in relation to other components - markers of the linguistic plane of discursive analysis. Thus, the concept of "scientific discourse" reveals a significant

\footnotetext{
${ }^{8}$ Дискурс як когнітивно-комунікативний феномен / Під заг. ред. Шевченко I.C. : Монографія. Харків : Константа. 2005. С. 233-236.
} 
closeness to such terms as "language style", "text", "communicative situation".

It is known that the modern Ukrainian formal language as a set of numerous linguistic units, which are used during communication in different situations, is a stylistically differentiated system. We distinguish the scientific style, directly related to the concept of "scientific discourse" among a number of historically formed language styles. According to S. Yermolenko it is "a functional kind of formal language used for cognitive and informative purposes in the field of science and education". In such a definition of scientific style science and education are relevant as the names of two branches, within which scientific terms that constitute an important section of the structure of this style are used the most actively. Particularly, it is impossible to imagine studying in higher education institutions that train Ukrainian philologists in various specialties without the use of linguistic terms. Recently, scholars of language have been actively studying the dichotomy "text" - "discourse", discovering all aspects that allow to define a comprehensive description of the communicative intentions of the text and its components. The linguistic tradition still has a great influence on the development of theoretical principles of categorization and classification of the concept of discourse, because until recently the discourse was often equated with the text as a complex linguistic sign that arises as a result of the process of language formation. Currently scholars outline the structural and semantic parameters of the text with a number of features that also appear relevant and objective for the discourse: completeness; coherence; integrity; lexical, grammatical, logical, stylistic, semantic coherence; compositional completeness; communicative and pragmatic orientation, etc. Because of this some linguists suggest that under certain conditions the text is a discourse. O. Perelomova notes that "Linguistic study of the text, the task of which is to identify not only the language instruments, but also the balance of linguistic and extralinguistic factors in the creation of a language work, is relevant in different aspects. One of the evaluation categories of such analysis is the theory of discourse" $"$. However, the rapid development of discourse theory in linguistics of the end of XX - the beginning of XXI century caused an urgent need to distinguish the content of the analyzed concepts, isolation and scientific development of their features.

${ }^{9}$ Срмоленко С.Я. Науковий стиль. Украӥнська мова : енциклопедія / редкол.: Русанівський В.М., Тараненко О.О. (співголови), М.П. Зяблюк та ін. Київ : «Укр. енцикл.», 2000. С. 372.

${ }^{10}$ Переломова О.С. Інтертекстуальність як системотвірна текстово-дискурсивна категорія. Гуманітарний вісник Запорізької державної інженерної академії. 07/2008. № 34. C. 95. 
Scientific text like any other (artistic, publicistic, informational, etc.) is often the basic unit of numerous communicative processes observed in the educational and professional sphere. It is characterized not only by internal structural connections between individual components, but also by a number of extralinguistic text-forming factors. For example, the content of a linguistic text can be exposed by actively involving a number of accompanying communicative, socio-cultural and cognitive factors during lectures and practical classes with students. Interpretation of the concept of "scientific discourse" in modern linguistics allows to combine the features of the text with the characteristics of the situational context, ie the discourse that operates a system of communicative-pragmatic and cognitive guidelines of the addresant (author, lecturer, etc.), which can be successfully implemented during its interaction with recipients (students).

In the science of the beginning of the XXI century in communicative linguistics, linguopragmatics, discourse, etc., the question of classification of the communicative acts observed in these or those social and industrial spheres where language interaction of communicators by all means takes place is urgent. Scientific communication is situationally outlined by the relevant institutions, which usually specialize in the study and generalization of previously unexplored facts, phenomena and so on. Such scientific communication or scientific-communicative situation is created and maintained by scholars, who objectify the results of their searches and arguments in professional texts. Many linguists consider scientific communication as a purposeful discursive practice, which is acquired not only by researchers of general or narrowly specialized issues, but also by all those who are involved in the study of the theoretical basis of certain scientific fields. Thus, scientific discourse that maintains special knowledge in various fields is important in the studying process, especially in higher education institutions. The scientific-discursive approach to the educational process structure is a priority in the field of theoretical and practical professional training of Ukrainian philologists.

Researchers often correlate this concept with other manifestations of discursive-communicative interaction when considering the features of scientific discourse in the field of higher education. For example, O. Litvinov suggests distinguishing a special type of scientific discourse, which is realized as pedagogical communication in the system of higher education. In this case, the communicative situation can be both "symmetrical" (interaction between equal communicators - partners who have the same scientific status and knowledge) and "complementary" (when the educational information transfers to a partner who usually does not yet 
have scientific degree and relevant scientific training and knowledge students, graduates $)^{11}$.

Scientific discourse has a complex structure. The Ukrainian linguists (F. Batsevych, T. Maslova, O. Morozova, O. Selivanova, I. Shevchenko etc.), who study the structure of scientific discourse in detail, suggested distinguishing its varieties not only by the communication scope of the participants of the particular communicative situations, but taking into account the peculiarities of the functioning of certain language units (most often professional terms) in different sciences. In this regard they suggest to classify various specific manifestations of scientific discourse in this way: 1) basically scientific (academic presentation, special informative orientation, addressing specialists); 2) popular science or scientific publicistic style (insighting non-specialists into the achievements of science); 3) scientific and business (patents, process descriptions); 4) scientific and educational (presentation of fundamental concepts to future specialists); 5) scientific and technical (specific technical component with elements of economic, environmental, social, political and other types of discourse); 6) scientific and conversational (oral form of discourse aimed at exchanging ideas, discussion and creative criticism) ${ }^{12}$.

In addition, according to the various communicative tasks that appear in the scientific discourse, traditionally the following genres are distinguished: 1) "nuclear", which determines the specifity of the discourse (scientific article, scientific and technical report, monograph, thesis work); 2) "peripheral", which do not form the basis of discourse (textbook, reference book, review, annotation, abstract, conference papers); 3) "allied", which are on the border between scientific and other types of discourse and tend to either "nuclear" (report, statement, scientific dialogue), or to "peripheral" (patent, regulation, lecture) genres ${ }^{13}$.

Recently, the typology of scientific discourse is being actively developed in connection with specific scientific fields. As a result of this distribution linguistic, philosophical, historical, geological, aviation, environmental and other

11 Литвинов А.В. Научный дискурс в свете межкультурной коммуникации. Филология в системе современного университетского образования. Москва : Изд-во УРАО, 2004. Вып. 7. С. 286.

12 Маслова Т.Б. Типологія наукового дискурсу в сучасній мовознавчій парадигмі. Англістика та американістика.[зб. наук. пращь] / ред. кол. : А.І. Анісімова (голов. ред.), Т.М. Потніцева (заст. голов. ред.) [та ін.]. Дніпропетровськ : ЛІРА, 2013. Вип. 10. С. 41-42.

${ }^{13}$ Троянская Е.С. Особенности жанров научной литературы и отбор текстов на различных этапах обучения научных работников иностранному языку. Функииональные стили. Лингвометодические аспекты. Москва : Наука, 1985. C. 192. 
discourses have been studied to some extent. Under the selection and analysis of varieties of scientific discourse usually take into account the following criteria: 1) common participants of communication (their status and situational communicative characteristics); 2) communication conditions (presuppositions, sphere of communication, chronotope, communicative environment); 3) communication structure (motives, goals, values and strategies, division, control of communication and variability of communication modes); 4) communication modes (channel and mode, tone, style and genre of communication, precedent-setting texts and discursive formulas) ${ }^{14}$.

A general review of scientific discourse classifications, conducted by researchers on the basis of various criteria and taking into account a number of its typological features, allows us to identify the linguistic discourse associated with educational and professional discourses that are in higher education institutions, which train future professionals in the educational program "Ukrainian Language and Literature". In our opinion, the types of discourses that determine the tone, style and genres of communication between teachers and students at the philological faculties of a number of Ukrainian universities are correlated as follows: professional discourse $\rightarrow$ scientific discourse $\rightarrow$ linguistic discourse. Vocational training of Ukrainian philologists is carried out in various forms, among which lectures and practical classes in certain linguistic disciplines serve a purpose.

\section{Linguistic discourse in the vocational training of Ukrainian philologists}

Linguistic and literary courses are important in the vocational training of students of philology who study according to the educational program "Ukrainian Language and Literature", which form the theoretical basis of knowledge and skills of future specialists of a wide occupational groups. In today's conditions, graduates of philological faculties have the opportunity to work in various educational and cultural institutions, government agencies, etc., they can hold such positions and carry out certain duties that require not only knowledge of the Ukrainian formal language as a systemstructural entity with its numerous units, but also to operate with many extralinguistic concepts that reflect the peculiarities of national history, culture, etiquette, and others. Due to this in university education there is an urgent need to update the curriculum through a series of elective courses,

14 Маслова Т.Б. Типологія наукового дискурсу в сучасній мовознавчій парадигмі. Англістика та американістика.[зб. наук. пращь] / ред. кол. : А.І. Анісімова (голов. ред.), Т.М. Потніцева (заст. голов. ред.) [та ін.]. Дніпропетровськ : ЛІРА, 2013. Вип. 10. С. 42. 
among which anthropocentric linguistic courses are relevant. Suggested courses are the following: cognitive linguistics, basics of conceptualism, Ukrainian linguistic cultural studies, Ukrainian ethnolinguistics, sociolinguistics, communicative linguistics, linguo-pragmatics etc. This type of the scientific and practical disciplines allow them to prepare properly for future job and to conscientiously perform certain social functions of the Ukrainian linguist by means of expanding the horizons and professional knowledge of students.

We think that the discursive approach to the teaching of anthropocentric linguistic disciplines, which make it possible to bring a person to the forefront in various linguistic and communicative situations, provides a high level of professional and educational training for future specialists. Such courses are developed from the perspective of the theoretical foundations of the relevant scientific fields, which consider a number of current issues related to human cognitive activity, the formation of its linguistic worldview, which is correlated with the concept of national-linguistic worldview. The outlined concepts appear to be crucial in cognitive linguistics, as well as in conceptualism and other scientific fields.

An important way to implement the discursive direction in the teaching of these elective courses is to acquaint students with the specifics of each scientific and practical course, determine object and subject of study, the formation of the basic concepts that define the content of the discipline in the minds of recipients. However, the most urgent task for the teacher is to acquaint students with the terminological apparatus, which operates an anthropocentric science. For example, cognitive linguistics, conceptualism, linguistic cultural studies primarily focus on the idea of concept. According to Z. Popova and J. Sternin - linguists who represent semantic-cognitive branch in cognitive linguistics, the concept is "discrete mental education, the basic unit of human thought code" 15 . If the representatives of cognitive linguistics consider mainly the linguocognitive concept as a result of cognitive activity of the individual and society, which transmits complex, encyclopedic information about the adduce object or phenomenon, the most important concept of linguistic cultural studies is cultural (linguocultural) concept ${ }^{16}$.

We emphasize that Ukrainian linguists (L. Belekhova, T. Vilchynska, O. Vorobyova, I. Golubovska, O. Kaganovska, V. Nikonova and others) are exploring the idea of the concept perhaps most actively. I. Golubovska emphasizes that concepts as a mental phenomenon realized in a certain

15 Попова З.Д., Стернин И.А. Когнитивная лингвистика : Учебное издание. Москва : АСТ: «Восток-Запад», 2007. С. 24.

${ }^{16}$ Там само. С. 10. 
linguistic culture in modern Ukrainian linguistic studies are studied within and at the intersection of two new areas of linguistic knowledge, which are linguocognitivism and linguocultural studies ${ }^{17}$.

Ukrainian linguists often combine methods of conceptual analysis of the subject of study in their works, which were developed in several linguisticcognitive schools.

In this regard cognitive poetics is expressive, this field was initiated in Ukrainian science by O. Vorobyov. Conducting researches on the mental formations found in the prose, poetic, dramatic works of English, French, and American writers, the representatives of this branch substantiated the need to classify the concepts into linguistic, culturological, and artistic; they structured concepts based on different methods of studying their structure; developed theoretical foundations for the study of various types of verbal and artistic images etc.

Thus, an extensive terminological system focused on the idea of concept has been developed in the research of the representatives of new linguistic branches such as cognitive linguistics and conceptualism: national-linguistic worldview, individual-linguistic worldview, concept and meaning, linguocognitive concept, linguocultural concept, textual (artistic) concept, semantic structure of the concept, nominative aspect of the concept, associative-interpretive aspect of the concept, cognitive code, concept, etc. Understanding of such basic concepts, which were developed within cognitive linguistics and conceptualism, occurs between teachers and students in the scientific-discursive form of communication when virtual materials are involved during lectures and practical classes, and different methods and forms of its study are used.

The main purpose of the elective course "Ukrainian Linguo-Cultural Studies" is to substantiate and comprehensively analyze the mechanisms of interaction of such concepts as "language" and "culture". The research field of linguocultural studies is interpreted differently by domestic, European and American scientists. This branch in linguistics maintains a number of concepts formed in the history of the Ukrainian people, its mentality, culture, and so on. Therefore, the object and subject of study of domestic linguoculturology often intersects with the tasks solved by modern ethnolinguistics (a science that "studies language as a creative product of its bearer, in ethnosociety, which gave rise to the language phenomenon as a

${ }^{17}$ Голубовська I.О. Сучасна українська лінгвоконцептологія: стан і перспективи розвитку. Актуальні проблеми філологї та перекладознавства : зб. наук. праць. Хмельницький : ФОП Бідюк С.І., 2016. Вип. Х. Т. 1. С. 154. 
key element and driving national culture") ${ }^{18}$. Ethnolinguistic signs such as folklore, phraseological units in particular, paremia (proverbs and sayings), folk songs and mythologisms usually come into the view of the developers of these scientific branches, which are related to each other. In modern conditions of functioning of higher education institutions, which train specialists in Ukrainian philology, these disciplines appear to be maintained components of linguistic discourse.

During the process of training Ukrainian philologists it is important to teach students how to communicate in different situations that are scientifically, socially or culturally dependent. The main role of linguists is the ability to create and maintain communication with participants in the communicative situation, outlined by the concept and essence of linguistic discourse and strategies for its implementation. In the field of higher education, schools are offered a number of elective linguistic disciplines: "Communicative Linguistics", "Linguopragmatics", "Social Linguistics", etc. Understanding of the theoretical foundations actually trains specialists in various philological specialties. Linguistic pragmatics as well as communicative linguistics explores the peculiarities of the use and functioning of language signs in the process of communication in connection with the interaction of the participants in this process - the speaker and the addressee. It also combines attention to language apparatus with its projection onto personal factors of communication and components of the communicative situation. In this way, linguistic pragmatics, based on the theory of traditional and innovative linguistic sciences, has not yet been clearly formed, but is extremely promising, it develops its own basis of the analysis of various factors (sociocultural, situational-behavioral, status, etc.) communicative interaction of subjects and their attitude to the linguistic and symbolic means used in the exchange of speech process which consists of units of normative socio-linguistic behavior within a pragmatic situation ${ }^{19}$.

Having mastered the scientific and theoretical foundations of another anthropocentric discipline as social linguistics, future specialists will know the history of this science, its problems and place among other sciences, the basic concepts of sociolinguistics, methods and techniques of sociolinguistic research, sociolinguistic functions of the world. They will be able to analyze different forms of language existence in society, to distinguish them, to conduct sociolinguistic research in the form of surveys, profiles, programs,

18 Жайворонок В.В. Українська етнолінгвістика : Нариси : Навч. посіб. для студ. вищ. навч. закл. Київ : Довіра, 2007. С. 8.

19 Бацевич Ф.С. Вступ до лінгвістичної прагматики. Київ : ВЦ «Академія», 2011. C. 286. 
questionnaires, etc. Such knowledge and skills are necessary for everyone who will continue to work in the degree field after graduating and successfully implement the ability to communicate in any professionally determined situation not only with individuals around the person, but also with the word itself.

\section{CONCLUSIONS}

An important public sphere in modern Ukraine is higher education institutions, which train specialists in various fields. One of the urgent tasks of classical universities, where future Ukrainian philologists usually study, is the development and implementation of a lerner-centered model of development of scientific and professional language. Structuring the classification matrix designed to train a qualified specialist allows to create an appropriate scientific and theoretical basis for the future of each specialist to be proficient in the terminological system of the Ukrainian language as the most important mean of communication.

The development of higher education in the field of philology, in particular linguistics, requires the search for new ways of implementing the educational program, the formulation of special guidelines for the practical application of the Ukrainian language knowledge. In this regard, scientific and practical anthropocentric courses, teaching and understanding of the theoretical foundations required by a discourse-centric approach are relevant in the system of linguistic disciplines offered to applicants for higher education in the field of Ukrainian philology.

The scholars who study modern discourse pay much attention to the problem of classification of discourses in their works. Systematic training of future philologists involves the use of professional discourse in the educational process, as professional discourse is a synthesis of professional identities, realized in the communicative activities of modern specialists.

Scientific and professional training of Ukrainian specialists in today's conditions requires significant changes in the system of higher education, which primarily consist of the development of new elective disciplines designed for comprehensive training of future philologists and their introduction to the educational program "Ukrainian Language and Literature". A discursive approach to the teaching of anthropocentric linguistic disciplines, which make it possible to bring a person to the forefront in various linguistic and communicative situations, provides a high level of vocational and educational training for future professionals.

\section{SUMMARY}

Peculiarities of scientific and professional discourse in professional training of Ukrainian philologists have been studied. The results of the study 
showed that the structuring of the classification matrix, designed to train a qualified specialist, allows to create an appropriate scientific and theoretical basis for further implementation of knowledge and skills acquired in the process of higher education. The structure of such a classification matrix is substantiated. It has been proved that the discourse-centric approach to the structure of the educational process is the most effective in higher education institutions. Typological features of professional discourse are determined. This article demonstrates that such notions as "scientific discourse" and "linguistic discourse" become relevant during the training of Ukrainian philologists. These terms consistently specify the notion of "professional discourse". In this article the issues and tasks of a number of scientific and practical linguistic disciplines of anthropocentric direction, which provide successful training of future specialists, are analyzed. It is concluded that the discursive approach to the teaching of such theoretical courses makes it possible to bring a person to the forefront in various linguistic and communicative situations, to ensure a high level of vocational training of future Ukrainian philologists.

\section{REFERENCES}

1. Арутюнова Н.Д. Дискурс. Лингвистический энциклопедический словарь / гл. ред. В. Н. Ярцева. Москва : Сов. энциклопедия, 1990. C. $136-137$.

2. Бацевич Ф.С. Вступ до лінгвістичної прагматики. Київ : ВЦ «Академія», 2011. $304 \mathrm{c.}$

3. Бацевич Ф.С. Філософсько-метологічні засади сучасної лінгвістики: спроба обгрунтування. Мовознавство. 2006. № 6. С. 33-40.

4. Войтко Т.В. Підходи до встановлення типології професійного дискурсу. URL: http://www.philol.vernadskyjournals.in.ua/journals/2019/ 3_2019/part_2/16.pdf.

5. Голованова Е.И. Категория профессионального деятеля: Формирование. Развитие. Статус в языке. Москва : Изд-во «Элпис», $2008.304 \mathrm{c}$.

6. Голубовська І.О. Сучасна українська лінгвоконцептологія: стан і перспективи розвитку. Актуальні проблеми філологї та перекладознавства : зб. наук. праць. Хмельницький : ФОП Бідюк С. І., 2016. Вип. Х. Т. 1. С. 151-159.

7. Дискурс як когнітивно-комунікативний феномен / Під заг. ред. Шевченко I.C. : Монографія. Харків : Константа. 2005. 356 с.

8. Срмоленко С.Я. Науковий стиль. Украӥнська мова : енциклопедія / редкол.: Русанівський В.М., Тараненко О.О. (співголови), М.П. Зяблюк та ін. Київ : «Укр. енцикл.», 2000. С. 372-373. 
9. Жайворонок В.В. Українська етнолінгвістика : Нариси : Навч. посіб. для студ. вищ. навч. закл. Київ : Довіра, 2007. 262 с.

10. Литвинов А.В. Научный дискурс в свете межкультурной коммуникации. Филология в системе современного университетского образования. Москва : Изд-во УРАО, 2004. Вып. 7. С. 283-289.

11. Маслова Т.Б. Типологія наукового дискурсу в сучасній мовознавчій парадигмі. Англістика та американістика. [зб. наук. праць] / ред. кол. : А.І. Анісімова (голов. ред.), Т.М. Потніцева (заст. голов. ред.) [та ін.]. Дніпропетровськ : ЛІРА, 2013. Вип. 10. 240 с.

12. Переломова О.С. Інтертекстуальність як системотвірна текстоводискурсивна категорія. Гуманітарний вісник Запорізької державної інженерної академії. 07/2008. № 34. С. 94-102.

13. Попова З.Д., Стернин И.А. Когнитивная лингвистика : Учебное издание. Москва : АСТ: «Восток-Запад», 2007. 224 с.

14. Ревзина О.Г. Лингвистика XXI века: на путях целостности теории языка. Критика и семиотика. Новосибирск, 2004. Вып. 7. C. $11-20$.

15. Серажим К. Дискурс як соціолінгвальне явище: методологія, архітектоніка, варіативність : монографія. Київ : Видавець Паливода А.В., 2010. 352 с.

16. Троянская Е.С. Особенности жанров научной литературы и отбор текстов на различных этапах обучения научных работников иностранному языку. Функииональные стили. Лингвометодические аспекты. Москва : Наука, 1985. с. 189-201.

\section{Information about the author:} Holikova N. S.,

Doctor of Philological Sciences, Associate Professor, Professor at the Department of Ukrainian Language Oles Honchar Dnipro National University 72, Gagarin Avenue, Dnipro, 49010, Ukraine 